\title{
IMPLEMENTASI JARINGAN SYARAF TIRUAN (JST) DAN PENGOLAHAN CITRA UNTUK KIASIFIKASI KEMATANGAN TBS KELAPA SAWIT
}

\author{
Minarni $^{1{ }^{1 *},}$ Roni Salumbae ${ }^{2}$, Zilhan Hasbi ${ }^{3, *}$ \\ ${ }^{1}$ Dosen Jurusan Fisika, \\ ${ }^{2}$ Jurusan Ilmu Komputer \\ ${ }^{3}$ Mahasiswa Program Studi S-1 Fisika \\ Fakultas Matematika dan Ilmu Pengetahuan Alam, \\ Universitas Riau Kampus Bina Widya \\ J1. Prof. Muchtar Luthfi Pekanbaru, 28293, Indonesia \\ *E-mail: minarni@unri.ac.id \\ zilhanhasbie25@gmail.com
}

\begin{abstract}
The clasification of ripeness stages of oil palm fresh fruit bunches (FFBs) can be done using color parameters. These parameters are often evaluated by human vision, whose degree of accuracy is subjective which can cause doubt in judgement. Automatic clasifications offreshfruit bunches (FFBs) based on color parameters can be done using computer vision. This method is known as a nondestructive, fast and cost effective method. In this research, a MATLAB computer program has been developed which consists of RGB and HSV GUI which is used to record, display, and process FFB image data. The backpropagation artificial neural network (ANN) program is also developed which is used to classify the oil palm fruit fresh bunches (FFBs). Samples are fresh fruit bunches $(F F B)$ of oil palm varieties of Tenera which comprise of Topaz, Marihat, and Lonsum clones. Each clone composed of three levels of ripeness represented by five fractions. The measurements were started by capturing images of oil palm, extracting RGB and HSV values, calculating weight values from the image database to make anANN program, preparing grid programs for oil palm FFBs, and comparing grading levels of oil palm FFBs using program and by harvester. This program successfully classified oil palm (FFBs) into three categories of ripeness which are unripe (F0 and F1), ripe (F1 and F1) and over ripe (F4 and F5). The $R G B$ and HSV programs successfully classified 79 out of 216 FFBs or $36.57 \%$ and 106 out of 216 TBS or 49.07\%. Respectively the HSV program is better than RGB program because the representation of HSV color space are more understood by human perception hence can be used in calibration and color comparison.
\end{abstract}

Keywords: fresh fruit bunches (FFBs), RGB, HSV, ANN, MATLAB.

\begin{abstract}
ABSTRAK
Penentuan kematangan TBS kelapa sawit dapat menggunakan parameter warna. Parameter ini secara manual dilakukan oleh penglihatan manusia. Kadar keakurasiannya bersifat subjektif yang dapat menyebabkan keraguraguan dalam penilaian. Penentuan kematangan TBS kelapa sawit secara otomatis berdasarkan parameter warna dapat dilakukan menggunakan computer vision. Metode computer vision bersifat tidak merusak, cepat dan hemat biaya. Pada penelitian ini, program komputer berbasis MATLAB dibuat yang terdiri dari dua bagian yaitu GUI (RGB) dan (HSV). Program ini berfungsi untuk merekam, menampilkan, mengolah data citra TBS. Program jaringan syaraf tiruan (JST) backpropagation juga dibuat untuk pengklasifikasian kematangan TBS kelapa sawit. Sampel adalah TBS kelapa sawit varietas Tenera klon Topas, Marihat dan Lonsum yang terdiri dari tiga tingkat kematangan yang diwakili oleh lima fraksi. Penelitian dimulai dengan pengambilan citra TBS kelapa sawit, mengekstraksi nilai RGB dan HSV, mencari nilai bobot dari citra database untuk pembuatan JST, pembuatan menu program grading TBS kelapa sawit dan membandingkan tingkat grading TBS kelapa sawit menggunakan program dan pemanen. Program ini berhasil mengklasifikasi TBS Kelapa Sawit kedalam tiga kategori kematangan: Kurang Matang (FO dan F1), Matang (F1 dan F1) dan Lewat Matang (F4 dan F5). Program RGB berhasil mengklasifikasi 79 dari 116 TBS atau sebesar 16,57 \% dan program HSV berhasil mengklasifikasi 106 dari 116 TBS atau sebesar 49,07\%. Program HSV lebih unggul dari pada program RGB karena penyajian ruang warna HSV dapat lebih dimengerti oleh persepsi manusia dan cocok untuk perbandingan warna.
\end{abstract}

Kata kunci: kematangan tandan buah segar kelapa sawit (TBS), RGB, HSV, JST, MATLAB. 


\section{PENDAHULUAN}

Kemajuan dalam bidang komputasi dan elektronika telah memungkinkan untuk otomatisasi secara digital pada perangkatperangkat manual yang digunakan dalam bidang pertanian atau perkebunan moderen. Otomatisasi dibidang pertanian perlu dikembangkan untuk meningkatkan efisiensi waktu dan biaya, kepresisian dan ramah lingkungan. Sistem otomasi adalah suatu teknologi yang membuat sebuah proses dapat dikerjakan tanpa bantuan manusia. Otomasi di implementasikan menggunakan program perintah yang dikendalikan oleh sistem kontrol yang kemudian akan dieksekusi oleh sistem kontrol [1]. Teknologi otomasi dalam bidang pertanian telah banyak dikembangkan salah satunya adalah sistem pemeriksaan kualitas otomatis non-destruktif untuk buah kelapa sawit [2], identifikasi kematangan buah jeruk dengan teknik jaringan syaraf tiruan [3], penentuan tingkat kematangan buah tomat menggunakan analisis citra [4], dan percobaan pengembangan peralatan grading otomatis untuk buah kiwi [5].

Pengklasifikasian buah dalam sistem sortasi memerlukan metode pencitraan digital (digital imaging) untuk menggantikan metode tradisional. Salah satu metode yang digunakan adalah metode computer vision. Computer vision merupakan kombinasi dari pengolahan citra (image processing) dan pengenalan pola (pattern regcognition). Pengolahan citra (image processing) berhubungan dengan proses transformasi citra. Proses ini bertujuan untuk mendapatkan kualitas citra yang lebih baik. Pengenalan pola (pattern recognition) berhubungan dengan proses identifikasi objek pada citra atau interpretasi citra. Proses ini bertujuan untuk mengekstrak informasi yang disampaikan oleh gambar. Gambar proyeksi dua-dimensi berasal dari dunia tiga-dimensi [6]. Computer vision merupakan sistem berbasis pada pengembangan algoritma dan komputer untuk menstimulasi visualisasi manusia agar dapat secara otomatis mengekstrak informasi berharga dari suatu obyek [7]. Beberapa penggunaan metode computer vision diantaranya, pengembangan sistem sortasi otomatis untuk TBS kelapa sawit [2], dan menentukan kematangan TBS kelapa sawit menggunakan teknik fuzzy logic yang diolah dalam bahasa pemograman MATLAB [8].

Jaringan syaraf tiruan (JST) dikembangkan sebagai generalisasi model matematik dan jaringan syaraf manusia [9]. Beberapa penelitian yang berhasil mengaplikasikan JST untuk menyelesaikan permasalahan identifikasi dengan pengolahan citra, diantaranya adalah identifikasi mata untuk pengenalan wajah [10], klasifikasi terumbu karang [11] dan identifikasi penyakit kanker paru-paru [12].

Penelitian ini tiga tahapan yang dilakukan yaitu ekstraksi, penerapan JST dengan algoritma backpropagation, dan pengukuran kinerja sistem. Tahap ekstraksi merupakan proses untuk mereduksi dimensi citra dengan melakukan segmentasi citra berdasarkan warna. Hasil ekstraksi ini digunakan untuk data masukan JST. Dengan dimensi data yang kecil waktu pelatihan JST lebih cepat. JST diproses dengan algoritma pelatihan backpropagation sehingga menghasilkan keluaran sesuai dengan pola yang terbentuk pada masukannya. Penilaian kinerja sistem dilakukan dengan mengukur konvergensi dan generalisasi keluaran sistem. Pemilihan objek citra TBS kelapa sawit didasari karena memiliki variasi warna yang berbagai ragam dan tidak seperti wajah atau sidik jari yang mempunyai derajat kemiripan yang tinggi dan memiliki ciri yang terdefinisi dengan baik. Pembagian fraksi TBS kelapa sawit yang biasanya ditentukan dipabrik sangat dipengaruhi perlakuan sejak awal panen dilapangan. TBS kelapa sawit berdasarkan warna kulit ketika matang dapat dibedakan menjadi tiga jenis yaitu Nigrescens (jingga hitam-hitaman), Virescens (jingga merah), Albescens (kuning dan ungu kehitaman) [9]. 


\section{TINJAUAN PUSTAKA}

\section{Sistem otomasi}

Sistem otomasi adalah teknologi yang berkaitan dengan aplikasi mekanik, elektronik yang berbasis komputer. Penggunaan komputer dalam suatu sistem otomasi akan menjadi lebih praktis karena dalam sebuah komputer berbagai komputasi dapat dilakukan. Tiga elemen dasar menjadi syarat mutlak bagi sistem otomasi yaitu sensor, aktuator, dan sistem kontrol yang mendukung proses dari sistem otomasi tersebut.

\section{Tingkat kematangan}

Tingkat kematangan TBS kelapa sawit diklasifikasikan menggunakan fraksi. Fraksi kematangan TBS didasarkan pada jumlah buah yang membrondol ketika TBS dipanen. Tabel 1 menunjukkan fraksi dan tingkatan kematangan yang digunakan sebagai standar penentuan fraksi TBS kelapa sawit secara tradisional [13].

Tabel 1. Tingkat Kematangan TBS.

\begin{tabular}{|c|c|c|c|c|}
\hline $\mathrm{N}_{0}$ & Kematangan & Fraksi & Jambh Brodolan & Keferangan \\
\hline \multirow[t]{3}{*}{1} & Mentah & 00 & $\begin{array}{l}\text { Tidak ads, buth berwama } \\
\text { Litam }\end{array}$ & Sengat mentah \\
\hline & & 0 & & Mentah \\
\hline & & & $\begin{array}{l}\text { Ihingsa } 12,5 \% \text { beah luar } \\
\text { mentrondd }\end{array}$ & \\
\hline \multirow[t]{4}{*}{2} & Matang & 1 & & Kurnag matane \\
\hline & & & $\begin{array}{l}12,5 \text { hings } 25 \% \text { buah luar } \\
\text { membroudol }\end{array}$ & \\
\hline & & 2 & & Matung I \\
\hline & & & $\begin{array}{l}25 \text { hings } 50 \% \text { bah luar } \\
\text { membrondd }\end{array}$ & \\
\hline \multirow[t]{6}{*}{3} & Lewatmatzog & 3 & & Matang 2 \\
\hline & & & $\begin{array}{l}50 \text { hingsa } 75 \% \text { beah lua } \\
\text { memitrondol }\end{array}$ & \\
\hline & & 4 & & Lewat mutung I \\
\hline & & & $\begin{array}{l}75 \text { tingsa } 100 \% \text { buah luar } \\
\text { membrovdel }\end{array}$ & \\
\hline & & 3 & & Levot matang II \\
\hline & & & $\begin{array}{l}\text { Buah dalam juga mesbrendal, } \\
\text { ada boal yang busuk }\end{array}$ & \\
\hline
\end{tabular}

\section{Representasi citra digital}

Citra digital adalah suatu fungsi identitas cahaya dua dimensi $f(x, y)$, dimana $x$ dan $y$ menunjukkan kordinat spasial. Nilal $\mathrm{f}(\mathrm{x}, \mathrm{y})$ pada tiap titik menunjukkan tingkat keabuan (gray level) citra pada titik tersebut [14]. Citra digital dapat berupa citra dalam skala keabuan atau citra berwarna (color). Setiap citra direpresentasikan dalam bentuk matrik berukuran $m x n$, dimana $m$ dan $n$ menunjukkan banyaknya elemen baris dan kolom pada matriks tersebut.

\section{Segmentasi warna}

Warna RGB mengandung tiga komponen warna yaitu merah (red), hijau (green) dan biru (blue) atau disebut juga sebagai warna primer [15]. Model warna RGB didasarkan pada sistem koordinat kartesian berbentuk kubus. Rentang nilai R, G, dan B merupakan representasi semua vektor warna dalarn ruang tiga dimensi R-G-B. Model warna RGB merupakan kombinasi dan tiga lapisan warna sehingga menghasilkan satu warna komposit. Pengambilan nilai informasi masing-masing unsur warna dilakukan dengan menormalisasi setiap unsur warna yang ditentukan oleh Persamaan (1), (2) dan (3) :

$$
\begin{aligned}
& r=\frac{R}{R+G+B} \\
& g=\frac{G}{R+G+B} \\
& b=\frac{B}{R+G+B}
\end{aligned}
$$

Untuk mendapatkan info kecerahan dari citra, nilai RGB dikonversi ke dalam model warna hue, saturation, dan value (HSV). Hue berhubungan dengan ragam warna adalah nilai sudut antara vektor warna aktual dan vektor warna referensi. Saturation berhubungan dengan kecerahan warna dan pencahayaan ditambah warna referensi.Value berhubungan dengan intensitas warna. Perbandingan warna RGB dan HSV dperlihatkan pada Gambar 1. 

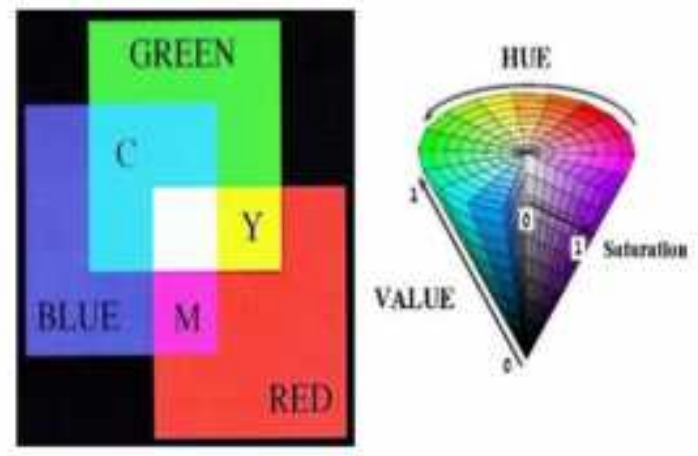

Gambar 1. Model warna RGB dan HSV.

Perhitungan nilai HSV berdasarkan nilai RGB dilakukan menggunakan persamaan (4), (5), (6), (7) dan (8). Max adalah nilai maksimum dan Min nilai minimum dari citra RGB.

$$
\begin{aligned}
& \mathrm{H}=0+60\left[\frac{(G-B)}{(M-M)}\right] ; \mathrm{R}=\mathrm{Max} \\
& \mathrm{H}=120+60\left[\frac{(B-K)}{(M-M)}\right] ; \mathrm{G}=\mathrm{Max} \\
& \mathrm{H}=240+60\left[\frac{(K-G)}{(M-M)}\right] ; \mathrm{B}=\mathrm{Max} \\
& \mathrm{S}=\frac{(M-M)}{M} \\
& \mathrm{~V}=\mathrm{Max}
\end{aligned}
$$

\section{Jaringan Syaraf Tiruan (JST)}

Jaringan syaraf tiruan (JST) adalah suatu sistem pemrosesan informasi yang memiliki karakteristik tertentu [9]. Arsitektur jaringan syaraf tiruan merupakan pola-pola hubungan antar neuron. Metode penentuan bobot-bobot pada hubungan itu disebut pelatihan (training) atau pembelajaran (learning). Fungsi aktivasi yang dijalankan masing-masing neuron pada masukan jaringan digunakan untuk menentukan sinyal keluaran. Setiap neuron memiliki aktivasi berupa suatu fungsi dan masukan yang diterima, dan kemudian mengirimnya sebagai sinyal ke beberapa neuron yang lain.

Algoritma back propagation sering digunakan pada JST. Algoritma backpropagationpada awalnya adalah hasil generalisasi aturan pembelajaran Widrow-Hoff pada jaringan dengan lapisan jamak dan fungsi transfer non-linier. Vektor masukan dan vektor keluaran yang berkorespondesi digunakan untuk melatih jaringan hingga fungsi mencapai nilai galat tertentu. Jaringan ini memiliki arsitektur lapisan jamak (multilayer) yaitu JST dengan lapisan input, satu atau lebih lapisan tersembunyi dan lapisan keluaran. JST ini dapat dilihat pada Gambar 2.

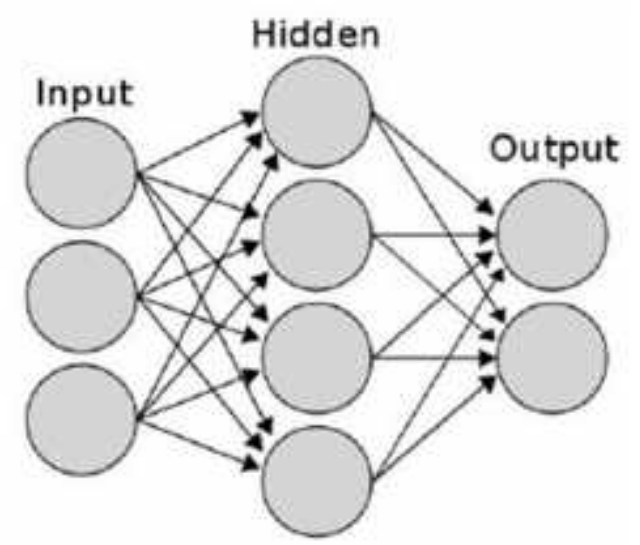

Gambar 2. Arsitektur jarinagan back propagation [9].

Tiga tahap pelatihan adapada JST backpropagation yaitu, pelatihan input yang berisi umpan balik (feed forward), perhitungan nilai galat propagasi balik, dan penyesuaian bobot [9].

\section{Pengukuran kinerja sistem}

Kinerja sistem diukur dengan menggunakan parameter konvergensi dan generalisasi. Konvergensi adalah tingkat kecepatan jaringan mempelajari pola input yang dinyatakan dalam satuan waktu atau satuan epoch. Satuan epoch adalah proses satu kali perulangan untuk melatih semua pasangan data pelatihan [16]. Generalisasi adalah tingkat pengenalan jaringan dalam mengenali sejumlah pola yang diberikan. Secara matematis generalisal dapat ditulis pada persamaan (9) [17].

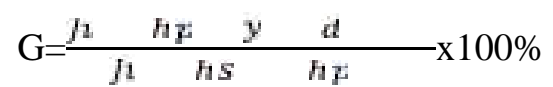




\section{METODE PENELITIAN}

Metode yang digunakan dalam penelitian ini adalah metode eksperimen yaitu untuk membuat program penentuan kematangan TBS kelapa sawit dengan computer visiondan jaringan syaraf tiruan (JST). Penelitian dimulai dengan pengambilan citra TBS kelapa sawit, mengekstraksi nilai RGB dan HSV dari citra TBS kelapa sawit, mencari nilai bobot dari citra database untuk pembuatan JST, dan membandingkan hasil klasifikasi TBS kelapa sawit menggunakan program dan pemanen.

Alat dan bahan yang digunakan dalam penelitian adalah TBS kelapa sawit, komponen computer vision dan alat-alat elektroniknya. Sampel TBS kelapa sawit yang digunakan dalam penelitian ini terdiri dari varietas tenera yaitu, marihat, topaz dan lonsum dengan 6 fraksi kematangan F0, F1, F2, F3, F4 dan F5. Untuk F0 dan F1 dikategorikan belum matang (unripe), F2 dan F3 dikategorikan matang (ripe) dan F4 dan F5 dikategorikan lewat matang (overipe) [18].

Penelitian ini terdiri dari beberapa tahap. Tahap pertama adalah perekaman citra TBS kelapa sawit varietas tenera dengan klon Marihat, Lonsum dan Topas. Tingkat kematangan sampel TBS yang diambil diklasifikasi secara manual oleh pemanen yang berpengalaman. Kalsifikasi ini akan dibandingkan dengan hasil klasifikasi JST.File dari citra TBS kelapa sawit ini disimpan dalam bentuk format BMP. Tahap kedua adalah pembuatan program untuk pengolahan citra TBS kelapa sawit. Program ini dibuat untuk menentukan nilai RGB dan HSV dari citra tersebut. Tahap ketiga adalah mencari nilai bobot citra untuk dijadikan database untuk pembuatan jaringan syaraf tiruan (JST).Masing-masing nilai bobot citra harus mendekati generalisasi $100 \%$.

Tahap keempat adalah pembuatan JST dari nilai bobot yang telah ditentukanagar sistem dapat mengenali sampel yang akan diuji. Tahap selanjutnya adalah persiapan klasifikasi menggunakan program RGB maupun HSV dengan beberapa jenis sampel TBS yang telah disediakan. Setelah keseluruhan TBS kelapa sawit diuji dengan program HSV dan RGB, perbedaan antara kedua program tersebut dianalisa. Perbandingan klasifikasi tingkat kematangan TBS kelapa sawit pemanen dan program JST akan dianalisa. Tahap terakhir adalah memperoleh kesimpulan dari eksperimen.

Skema penelitian pengambilan citra TBS kelapa sawit diperlihatkan pada Gambar 3.

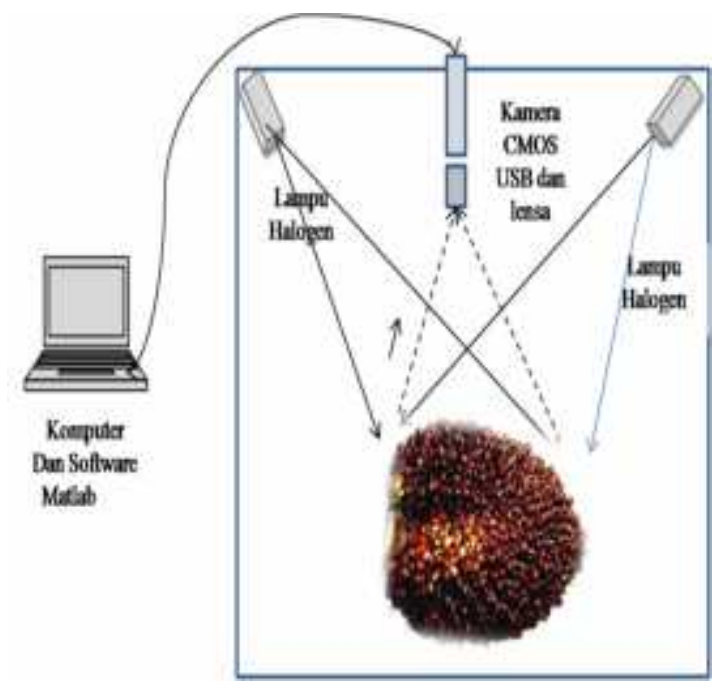

Gambar 3.Skema pengambilan citra TBS kelapa sawit.

Sistem computer vision ini terdiri dari dua lampu neon, satu kamera RGB, USB penghubung dan sebuah laptop/komputer. Pada penelitian ini digunakan kamera RGB merkAmScope dengan ukuran sensor 0,5 inch, ukuran pixel 2048 x 1536. Kamera digunakan untuk merekam citra TBS kelapa sawit. Hasil rekaman citra disimpan dalam bentuk format BMP dengan gambar tampak sisi depan dan belakang pada bagian tengahnya. Data hasil citra TBS kelapa sawit ini yang akan dicari nilai matriknya.

\section{Program MATLAB}

Program JST berbasis MATLAB dapat diliahat pada flowchart Gambar 4. Program digunakan untuk pembuatan menu klasifikasi kematangan TBS kelapa sawit yang berfungsi memanggil citra TBS sampel yang akan diuji.Proses pertama adalah membuka program 
klasifikasi ini dengan menginput database yang telah disiapkan dalam pembuatan JST sebelumnya.

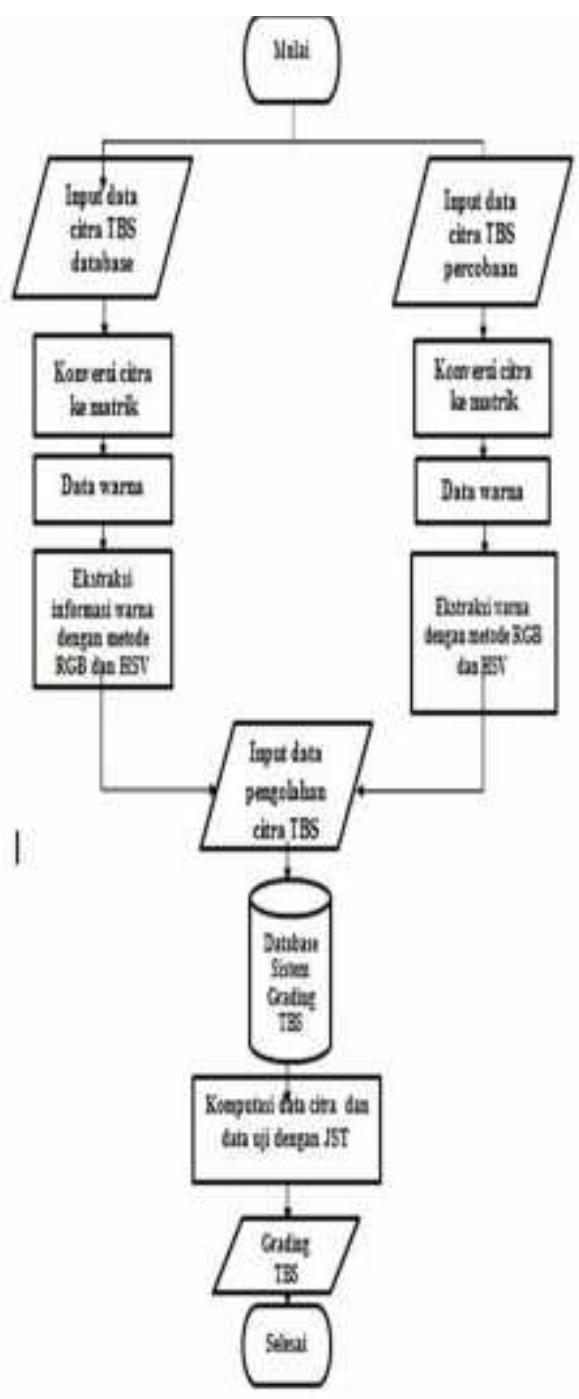

Gambar 4. Flowchart Program.

Data citra yang diinput dalam bentuk format BMP dan program MATLAB akan memanggil filenya ketika ingin diuji. Program JST ini diawali dengan menginput database citra program sebagai acuan dan data citra TBS yang akan diuji. Program secara otomatis mengkonversikan citra yang diinput kedalam nilai matriks RGB dan HSV tergantung jenis program yang digunakan. Setelah proses konversi dilakukan, JST akan mengklasifikasi citra percobaan sesuai dengan database. Selanjutnya, program akan mengklasifikasi citra berdasarkan tiga kategori yang telah ditentukan.

\section{HASIL DAN PEMBAHASAN}

Penelitian ini bertujuan untuk menentukan tingkat kematangan TBS kelapa sawit secara otomatis menggunakan jaringan syaraf tiruan (JST) menggunakan nilai matriks RGB dan HSV.Penelitian ini menggunakan sistem computer vision yang terintegrasi dengan sistem grading TBS kelapa sawit. Foto computer vision ini dilihat pada Gambar 5.

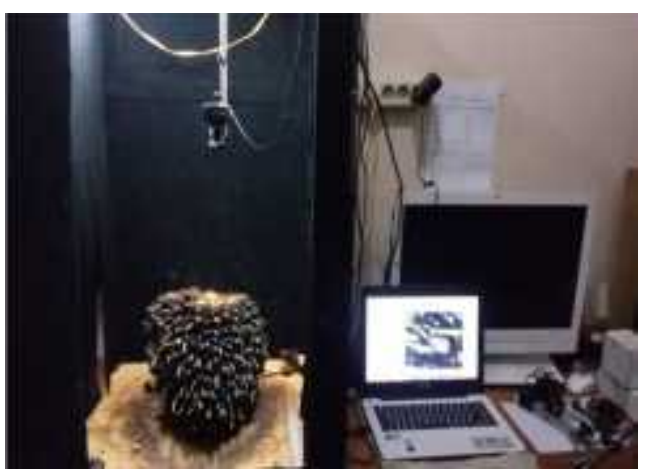

Gambar 5. Sistem computer vision.

Sampel diletakkan didalam box berwarna hitam yang terbuat dari alkrilik yang telah di set alat perekaman citra, dan jarak antara kamera kesampel $34 \mathrm{~cm}$. Box digunakan untuk mengisolasi citra dari cahaya ruang. Pengambilan citra dilakukan saat box ditutup rapat dan cahaya lampu telah dihidupkan.

\section{Pengolahan citra MATLAB}

Proses penentuan nilai RGB dan HSV menggunakan program dapat pada Gambar 6.

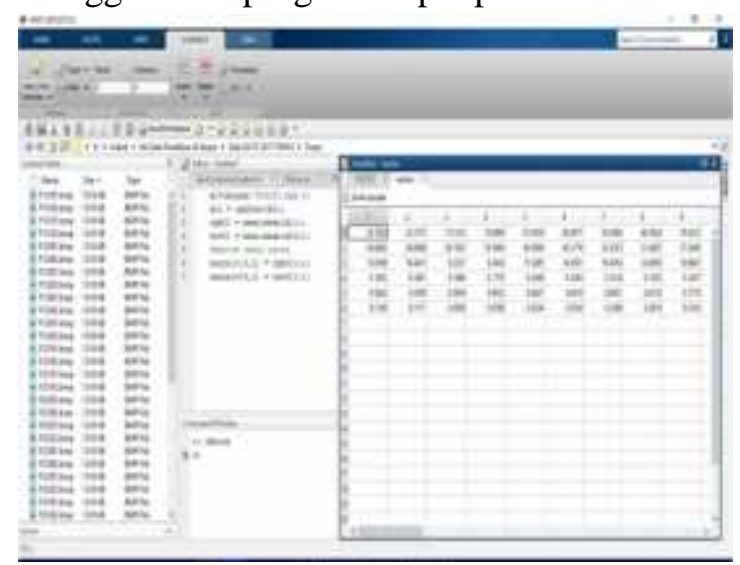

Gambar 6.Proses penentuan nilai RGB dan HSV. 
Pengolahan citra TBS kelapa sawit dilakukan dengan memasukkan algoritma kedalam program MATLAB. Pada menu home $=>$ new scripts, muncul kotak dialog yaitu editor untuk memasukkan algoritma RGB dan HSV dan citra TBS kelapa sawit. Kemudian algoritma tersebut disimpan dan dijalankan pada command window. Nilai R, G, B, H, S, dan V dapat dilihat pada variabel.

\section{Penentuan nilai bobot citra}

Nilai bobot dari citra dicari menggunakan program berbasis MATLAB dengan cara memasukkan algoritmanya. Nilai bobot citra ini diperlukan untuk menjadi acuan dalam memilih suatu citra untuk menjadi database/data acuan dalam pembuatan JST. Nilai bobot ini diperlukan dalam program sebagai seberapa kuat JST bisa mengenali data acuan yang telah diolah.Proses mencari nilai bobot citra ini terlihat pada Gambar 7.

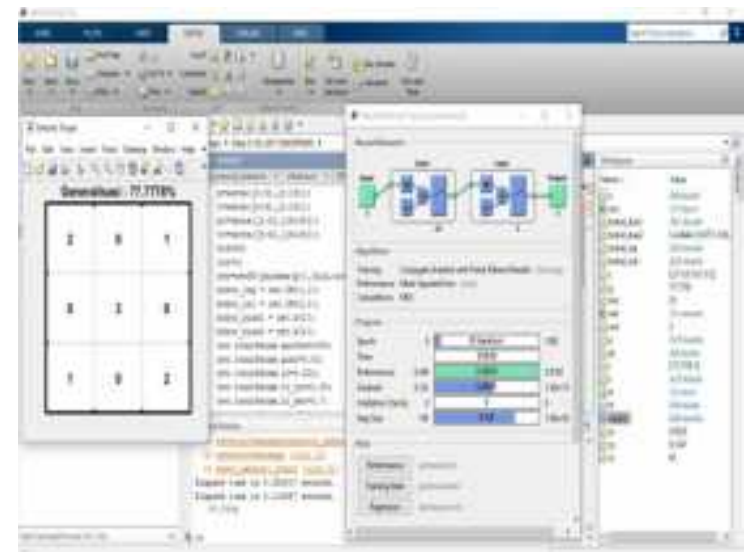

Gambar 7. Proses mencari nilai bobot citra.

Pencarian nilai bobot citra menggunakan matriks $6 \times 24$. Dimana 24 adalah data matriks dalam bentuk hidden dan 3 adalah output yang akan dibaca oleh JST yang sedang diuji. Dapat dilihat generalisasi dari citra tersebut sebesar $77,7778 \%$. Generalisasi diatas berbentuk kolom 3x3 yang mana menunjukkan baris pertama untuk kategori unripe, baris kedua ripe dan baris ketiga over ripe. Pada baris pertama dari 3 data yang menjadi output, 2 citra terdeteksi dengan benar dan 1 citra salah. Pada baris kedua, 3 citra terdeteksi benar dan pada baris ketiga, 2 citra terdeteksi benar dan 1 citra salah. Data citra ini lah yang nantinya akan dijadikan data acuan/database dalam grading TBS kelapa sawit.

\section{Jaringan Syaraf Tiruan (JST) dan tingkat kematangan}

Pada penelitian ini jumlah total TBS yang diuji berjumlah 216 buah yang terdiri dari 3 jenis yaitu, Marihat, Lonsum dan Topas. Keseluruhan jenis TBS akan diuji dengan menggunakan sistem program yang telah dibuat dengan besaran nilai RGB dan HSV.

\section{JST RGB dan tingkat kematangan}

Pada pengujian ini 3 jenis TBS kelapa sawit akan diuji tingkat kematangannya berdasarkan program yang telah dibuat. Tabel 2 menunjukkan hasil pengujian program RGB dengan jenis TBS kelapa sawit.

Tabel 2. Program JST RGB

\begin{tabular}{|c|c|c|c|c|c|c|c|c|c|}
\hline \multirow{2}{*}{ Fraksi } & \multicolumn{2}{|c|}{ Marihat } & \multirow{2}{*}{$\%$} & \multicolumn{2}{|c|}{ Lonsum } & & \multicolumn{2}{|c|}{ Topas } & \\
\hline & A & D & & $A$ & D & & A & D & \\
\hline F0 & 12 & 4 & $33.33 \%$ & 8 & 6 & $75 \%$ & 4 & $\overline{3}$ & $75 \%$ \\
\hline Fl & 12 & 8 & $66.67 \%$ & 12 & 4 & $33.33 \%$ & 12 & 9 & $75 \%$ \\
\hline F2 & 12 & 2 & $16.67 \%$ & 16 & 10 & $62.50 \%$ & 12 & 9 & $75 \%$ \\
\hline F3 & 12 & 3 & $25 \%$ & 36 & 4 & $111.11 \%$ & 12 & 2 & $16.67 \%$ \\
\hline $\mathrm{F} 4$ & & 0 & $0 \%$ & & 8 & $28.57 \%$ & 4 & 3 & $75 \%$ \\
\hline F5 & & & & & 4 & $33.33 \%$ & & & \\
\hline Total & 60 & 17 & $28.33 \%$ & 112 & 36 & $32.14 \%$ & 44 & 26 & $59 \%$ \\
\hline
\end{tabular}

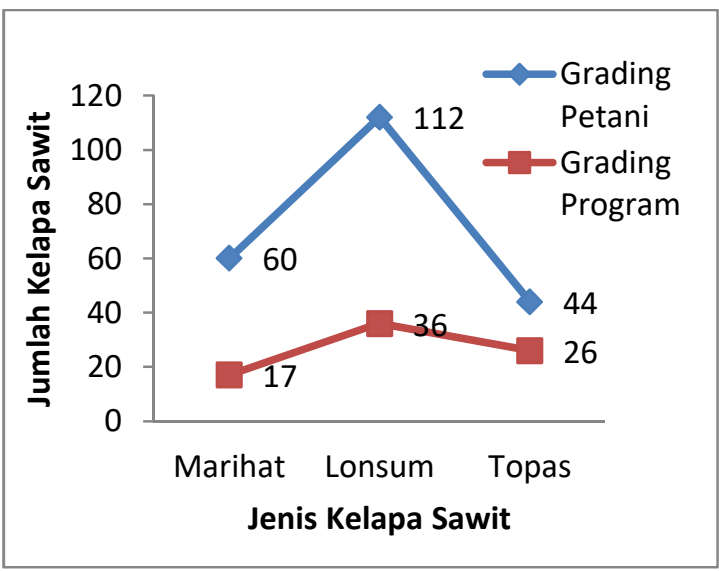

Gambar 8. Perbandingan Grading masingmasing jenis TBS oleh Sistem Program. 
Tabel 2 memperlihatkan bahwa secara keseluruhan dari jenis TBS yang diuji sistem program dapat mengenali tingkat kematangan tertinggi pada jenis TBS Topas yaitu mengenali 26 dari 44 sampel TBS yang disediakan atau sebesar 59\%. Sedangkan jenis TBS yang paling kecil dikenali adalah jenis Marihat yaitu sebesar 28,33\% atau mengenali 17 dari 60 sampel TBS yang disediakan. Perbandingan ini dapat dilihat pada Gambar 8.

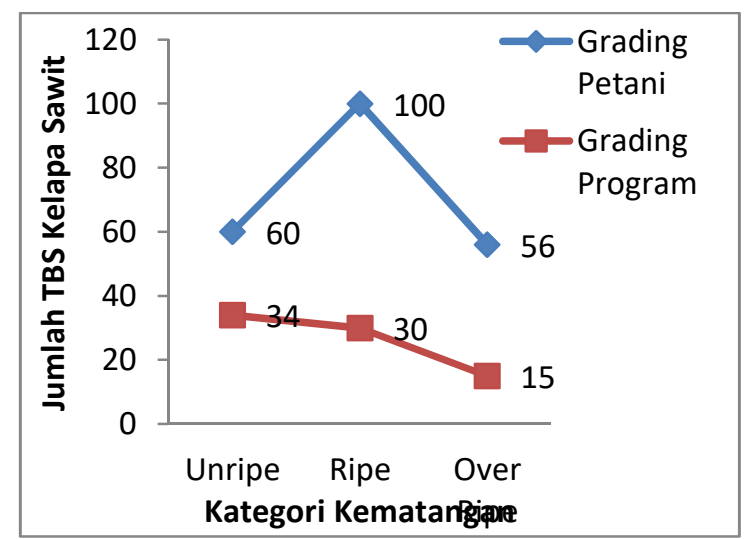

Gambar 9. Grading TBS kategori Kematangan

Gambar 9 diatas menjelaskan bahwa sistem program dominan lebih dapat mnegenali pada kategori unripe yaitu sebesar $56,7 \%$ yaitu mengenali 34 dari 60 Sampel yang dikenali. Hal ini diakibatkan karena kategori unripe ini warna yang dominan adalah warna hitam yang lebih mudah dikenali oleh program. Sedangkan untuk kategori ripe dan over ripe hanya sebesar $30 \%$ dan $26,8 \%$. Hal ini diakibatkan karena pada kategori ini warna RGB nya tidak ada yang dominan dan tidak konsisten sehingga program sulit mengenali sampel tersebut. Namun secara keseluruhan metode RGB ini dapat mengenali $36,6 \%$ atau sebesar 79 dari 216 sampel TBS Kelapa Sawit yang disediakan.

\section{JST HSV dan tingkat kematangan}

Pada pengujian ini 3 jenis TBS Kelapa Sawit akan diuji tingkat kematangan nya berdasarkan program yang telah dibuat. Tabel
4.2 menunjukkan hasil pengujian program HSV dengan jenis TBS kelapa sawit Lonsum.

Tabel 3. Program HSV

\begin{tabular}{|c|c|c|c|c|c|c|c|c|c|}
\hline \multirow{2}{*}{ Fraksi } & \multicolumn{2}{|c|}{ Marihat } & \multirow{2}{*}{$\%$} & \multicolumn{2}{|c|}{ Lonsum } & \multirow{2}{*}{$\%$} & \multicolumn{2}{|c|}{ Topas } & \multirow{2}{*}{$\%$} \\
\hline & A & D & & A & D & & A & D & \\
\hline $\mathrm{F} 0$ & 12 & 9 & $75 \%$ & 8 & 6 & $75 \%$ & 4 & 4 & $100 \%$ \\
\hline F1 & 12 & 0 & $0 \%$ & 12 & 5 & $41.67 \%$ & 12 & 10 & $83 \%$ \\
\hline $\mathrm{F} 2$ & 12 & 7 & $58.33 \%$ & 16 & 9 & $56.25 \%$ & 12 & 0 & $0 \%$ \\
\hline F3 & 12 & 12 & $100 \%$ & 36 & 26 & $72.22 \%$ & 12 & 0 & $0 \%$ \\
\hline F4 & 12 & 0 & $0 \%$ & 28 & 12 & $42.86 \%$ & 4 & 4 & $100 \%$ \\
\hline F5 & & & & 12 & 2 & 16.17 & & & \\
\hline Total & 60 & 28 & $46.67 \%$ & 112 & 60 & $53.57 \%$ & 44 & 18 & $40.91 \%$ \\
\hline
\end{tabular}

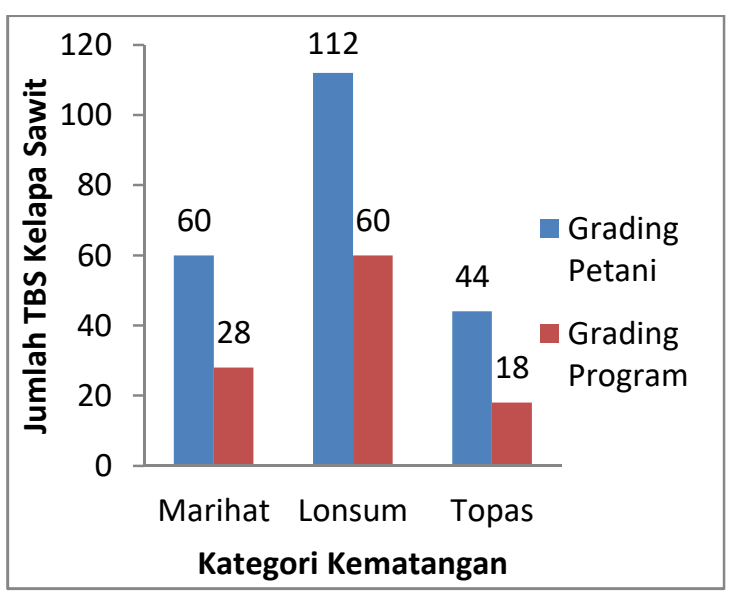

Gambar 10. Perbandingan grading masingmasing jenis TBS oleh sistem program.

Tabel 3 menjelaskansecara keseluruhan program HSV ini dapat mengenali seluruh TBS sampel yang disediakan sebesar $49,1 \%$ yaitu mengenali 106 dari 216 TBS kelapa sawit yang disediakan. Sedangkan jenis TBS yang paling tinggi gradingnya adalah jenis Lonsum yaitu sebesar $53,57 \%$ yaitu mengenali 60 dari 112 sampel TBS kelapa sawit yang disediakan.

Gambar 11 adalah hasil grading masingmasing fraksi dijadikan tiga kategori kematangan unripe, ripe dan over ripe. Hasil Grading TBS berdasarkan Kategori Kematangan dapat dilihat bahwa program HSV ini secara keseluruhan dapat mengenali 49,1\% atau 106 dari 216 sampel TBS yang yang disediakan. Untuk grading tertinggi terdapat pada ketegori unripe sebesar 56,7\% mengenali 34 dari 60 sampel TBS kelapa sawit 
yang disediakan. Sedangkan grading kategori terendah pada over ripe sebesar 32,1\% mengenali 18 dari 56 sampel TBS yang disediakan.

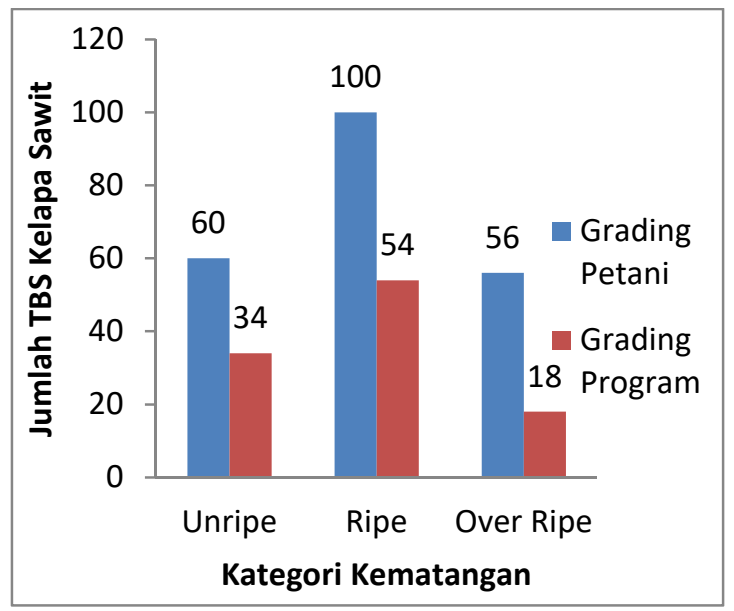

Gambar 11. Hasil grading TBS berdasarkan kategori kematangan.

\section{KESIMPULAN}

Beberapa kesimpulan dapat diambil dari hasil penelitian ini. Ekstraksi ciri dengan proses segmentasi warna berfungsi untuk mereduksi dimensi citra sehingga dihasilkan nilai sample mempresentasikan informasi citra untuk masukkan JST. Perbandingan JST RGB dan HSV memperlihatkan bahwa program HSV lebih unggul dari RGB karena persentasi dalam mengenali HSV lebih besar dibandingkan RGB yaitu 49,07\% berbanding 36,57\%. RGB memprioritaskan warna yang dominan (R-G-B) untuk klasifikasi kematangan, sehingga keakuratannya kurang maksimal. Fungsi penglihatan salah satu cara tradisional yang tingkat keakurasiannya kuranglah efektif.

\section{DAFTAR PUSTAKA}

1. Groover, M. (2001). Automation, Production Systems and Computer Integrated Manufacturing. (Ed. 2). New Jersey: Prentice Hall.

2. Makky, M., Soni, P., \& Salokhe, V. M. (2014). Automatic non-destructive quality inspection system for oil palm fruits. International Agrophysics, 28: 319-329.

3. Warman, K. (2015). Identifikasi Kematangan Buah Jeruk dengan Teknik Jaringan Syaraf Tiruan. Teknik Pertanian USU. Medan. Jurnal Rekayasa Pangan dan Pertanian, 3(2).

4. Choi, K. (1995). Tomato maturity evalution using color image analysis. American Society of Agricultural Enginers, 36, 171-176.

5. Xu, L. (2013). Development and Experiment on automatic grading equipment for kiwi. Sichuan Agriculture University Ya'an China. College of Information and Engineering Technology INMATEH, 4(1).

6. Jaffar, A., Jamil, N., Low, C. Y., \& Abdullah, B. (2009). Photogrammetric Grading of Oil Palm Fresh Fruit Bunches. International Journal of Mechanical and Mechatronics Engineering, 9(10).

7. Panigrahi, S. (2001). NondestructiveFood Evaluation Techniques to Analyze Properties and Quality. Marcel Dekker, Inc., New York.

8. May, Z. \& Amaran. (2011). Automated oil palm fruit grading system using artificial inteligence. Int. J. Eng. Sci, 11, 30-35.

9. Fauset, L. (1994). Fundamentals of Neural Networks (Architectures, Algorithms, and Application). Prentice-Hall, New Jersey.

10. Eide, A., Jahren, C., Jorgensen, S., Lindblad, T., Lindsey, C. S., \& Osterud, K. (1994). Eye Identification for face Recognition with Neural Networks. Diakses pada 10 November 2017. URL: www.it.hiof.org. 
11. Marcos, M. S. A. C., Sorjano, M. N., \& Saloma, C. A. (2005). Classification Of Coral Reef Images From Underwater Video Using Neural Networks. Optical Society of America.

12. Zhou, Z.-H., Jiang, Y., Yang, Y.-B., \& Chen, S.-F. (2002). Lung Cancer Cell Identification Based on Artificial Neural Network Ensembles. Artificial Ingeligence in Medicine, 24(1), 25-36.

13. BACP. (2014). Petunjuk Praktis: Budidaya Kelapa Sawit Ramah Lingkungan untuk Petani Kecil. BACPPanEco Booklet. Diakses pada tangga 20 November 2017. URL: www.ifc.org.

14. Gonzales, R. C. \& Wood, R. E. (2002). Digital Image Processing, Second Edition. Prentice Hall, Inc, New Jersey.
15. Pitas, I. (1993). Digital Image Processing Algorithms. Prent Hall, London.

16. Kusuma, S. \& Hartati, S. (2006). NeuroFuzzy: Integrasi Sistem Fuzzy dan Jaringan Syaraf. Yogyakarta: Graha Ilmu.

17. Hoekstra, A. (1998). Generalisation in Feed Forward Neural Clasifier, Dissertation Netherlands: Delft Universiteit, Netherlands.

18. Hafiz, M., Hazir, M., Rashid, A. \& Amirrudin, M. D. (2011). Determination Of Oil Pal Fresh Fruit Bunch Ripeness Based On Flavonoid And Antocyanin Content. Elvesier Industrial Corps and Products, 36, 466-475. 